\section{Reprints: more for than against}

SIR-Current awareness publications such as the Current Contents series play an important role in disseminating information about where to find published research. But there can be no doubt that these information tools contribute to the problem described by Ivor Smith (Nature 336, 708; 1988), the indiscriminate use of reprint requests.

In 1988, I published two articles dealing with the history of molecular biology; one article described the discovery of RNA splicing and the other gave and discussed a somewhat tongue-in-cheek list of significant discoveries in molecular biology over the past fifty years. The articles appeared in sister review journals Trends in Biochemical Sciences (13, 110113; 1988) and Trends in Biotechnology (6, 234-243; 1988) respectively — but whereas the former article generated more than 250 reprint requests, the latter attracted only one-fiftieth of that number. It might be argued that the splicing article was simply a better article, but I ascribe the difference in my mailbag to another factor. Trends in Biochemical Sciences is listed in Current Contents Life Sciences, while Trends in Biotechnology is not.

JAN A. WITKOWSKI

Banbury Center,

Cold Spring Harbor Laboratory,

PO Box 534,

Cold Spring Harbor,

New York 11724, USA

SIR-Ivor Smith's criticism of the reprint, on the basis of costs and inconvenience alone, ignores the real merits of this form of scholarly communication. Reprints represent a direct, shorthand way for scholars to get in touch with others doing similar work. This personal contact is important, as it may lead to further communications, or perhaps later collaboration on some research. There is also the psychological value of knowing that others are interested in one's work. This immediate, favourable feedback undoubtedly inspires many authors to pursue their work with renewed vigour.

Contrary to Smith's belief, thousands of researchers around the world, especially in developing countries, do not have easy access to the published literature, so photocopying is a moot issue. For others, reprints are the only convenient medium for developing good subject collections, in cases where the literature is widely dispersed in various fields or simply unavailable because of inadequate distribution of the original journals.

Finally, reprints, printed on quality paper, are an excellent archival medium for personal libraries and ultimately research libraries which receive these materials as part of gift collections.
Arguably, some abuse the privilege of requesting reprints, but the case for reprints is too great to stop their use altogether.

\section{Natural Resources Research}

JOHN H. SANDY

\section{Institute,}

University of Minnesota, Duluth,

Duluth, Minnesota 55811, USA

SIR-I take exception to Ivor Smith's suggestion that photocopying replace the reprint. There are at least six reasons why reprints should survive.

(1) Many young faculty send reprints to more established colleagues as a simple but powerful way of making professional contacts.

(2) Many academic search committees require that applicants provide copies or reprints of recent publications. Young people seeking a permanent position may apply for dozens of jobs a year. They cannot be expected to bear the burden of photocopying 100 or more pages each time.

(3) Many of us do not have grants to cover the considerable cost of photocopying the large number of papers we need to read each week.

(4) Many university departments have photocopiers, but the smaller institutions do not permit unlimited photocopying.

(5) Most small universities do not have library subscriptions to all the appropriate journals. Consequently, we have to keep abreast of the literature by scanning Current Contents, Current Advances, Biological Abstracts and so on. Thus, the only way to obtain many titles is to request a reprint from the author.

(6) Many journals provide at least 50 free reprints. Why not save one's photocopying money, use it to buy extra reprints, and be kind enough to honour reprint requests?

At the very least, one could provide reprints to people one has never heard of (and who are therefore likely to be students or otherwise needy), to people at poorer institutions or departments and to people one happens to know are struggling financially.

\section{Biology Department,}

Christopher P. Dunn

Ball State University,

Muncie, Indiana 47306, USA

\section{No closure}

SIR-A. J. Southward (Nature 337, 202; 1989) claims that the Natural Environment Research Council (NERC) "is proposing to run down" the Biological Records Centre at Monks Wood, on the basis of an article in The Biologist (whose author is identified by the pseudonym
"Peccavi"!).

It is not NERC's intention to run down the Biological Records Centre (BRC). NERC fully recognizes the importance of biological recording and is actually strengthening the capability at Monks Wood by forming a new Environmental Information Centre. This will bring together the $\mathrm{BRC}$ and staff involved in remote sensing and data handling and will involve the transfer of additional staff to Monks Wood.

Furthermore, NERC is convening a meeting to discuss the implementation of the recommendations of the recent Linnean Society report Biological Survey: Need and Network, which should lead to improvements in this field.

P. B. TINKER

Natural Environment Research Council,

Terrestrial and Freshwater Services,

Polaris House, North Star Avenue,

Swindon SN2 IEU, UK

\section{Science funding}

SIR-You are right to warn against complacency about science funding ("Safeguarding British research", Nature 337, 291; 1989). However, there is a note of complacency in your analysis of the problem. You suggest that if only the government would understand the economic usefulness of basic research, it would provide adequate funding. In addition, if only young people would appreciate the excitement of a research profession, academic science would be restored. Both premises are questionable. Rather than addressing only the avowed economic imperatives for government science policy, your article should also have examined the hidden political reasons behind the underfunding of academic science.

Academics have traditionally had the freedom not only to pursue novel scientific theories but also to consider and act on the wider implications of their research and of world events. As illustrated by your article, underfunding science ties up scientists' political energies in defending their economic usefulness. Furthermore, the current scramble for grants, meagre salaries and scarce university positions in the United Kingdom (which I recently left), selects against young people with interests wider than their research profession. The government, by simultaneously removing the financial security and career prospects of university positions, and undermining the social image and status of academics, is silencing a traditionally liberal and outspoken section of society.

The serious and lasting damage is indeed that done in people's minds. It is that we no longer dare to ask for intellectual freedom.

Marie Rose van Schravendiuk 4277 Pomona Avenue,

Palo Alto, California 94306-4313, USA 